\title{
PENGARUH MODEL PEMBELAJARAN TEAM GAMES TOURNAMENT (TGT) BERBANTUAN MEDIA PERMAINAN ULAR TANGGA TERHADAP HASIL BELAJAR MATEMATIKA
}

\author{
Ni Kd. Dewiyanti ${ }^{1}$, I Kt Adnyana P. ${ }^{2}$, I W. Wiarta ${ }^{3}$ \\ 1,2,3 Jurusan PGSD, Universitas Pendidikan Ganesha, Singaraja, Indonesia \\ E-mail: dewicomel19@yahoo.co.id ${ }^{1}$, adnyana.putra54@gmail.com², \\ wayanwiarta.63@gmail.com ${ }^{3}$
}

\begin{abstract}
ABSTRAK
Penelitian ini bertujuan untuk mengetahui pengaruh model pembelajaran Team Games Tournament (TGT) berbantuan media permainan ular tangga terhadap hasil belajar matematika siswa kelas IV SD gugus VIII Mengwi, Badung. Penelitian ini merupakan penelitian eksperimen dengan rancangan penelitian yang digunakan adalah rancangan kelompok Non-ekuivalen. Populasi dalam penelitian ini adalah seluruh siswa kelas IV di SD Gugus VIII Mengwi, Badung yang berjumlah 243 siswa. Sampel penelitian ini sebanyak 60 siswa yang ditentukan menggunakan teknik random sampling. Metode pengumpulan data dalam penelitian ini adalah metode tes. Data yang diperoleh dianalisis menggunakan uji-t dengan rumus polled varians. Hasil penelitian berdasarkan analisis data, diperoleh harga thitung $=4,10>$ ttabel $=2,000$ dengan taraf signifikan $5 \%$ dan $\mathrm{dk}=58$, maka $\mathrm{H} 0$ ditolak dan Ha diterima. Hal ini membuktikan bahwa terdapat perbedaan yang signifikan hasil belajar matematika antara kelompok eksperimen dan kelompok kontrol pada kelas IV SD Gugus VIII Mengwi, Badung. Nilai rata-rata juga menunjukkan bahwa hasil belajar matematika yang diperoleh siswa kelompok eskperimen $=79,35>=72,85$ siswa kelompok kontrol. Dengan demikian dapat disimpulkan bahwa model pembelajaran Team Games Tournament (TGT) berbantuan media permainan ular tangga terhadap hasil belajar matematika siswa kelas IV SD gugus VIII Mengwi, Badung.
\end{abstract}

Kata Kunci: Team Games Tournament (TGT), Permainan Ular Tanngga, Hasil Belajar Matematika

\begin{abstract}
This study aimed to determine the effect of learning model Team Tournament Tournament (TGT) assisted by the game media snake ladder of mathematics knowledge of fourth grade students of SD group VIII Mengwi, Badung. This research was an experimental research with the research design used is a Non-equivalent group design. The population in this study were all students of grade IV at SD Gugus VIII Mengwi, Badung which amounted to 243 students. The sample of this research as many as 60 students determined using random sampling technique. Data collection method in this research was test method. The data obtained were analyzed using t-test with the formula of polled variance. The result of research based on data analysis, obtained tcount $=4,10>$ ttable $=2.000$ with $5 \%$ significant level and $\mathrm{dk}=58$, then $\mathrm{H} 0$ rejected and $\mathrm{Ha}$ accepted. This proves that there is a significant difference of mathematical knowledge between the experimental group and control group in the fourth grade of Gresik VIII Mengwi, Badung. The mean score also indicates that the mathematical knowledge obtained by experimental group students $=79,35>=72,85$ students of the control group. The conclution of this study is the Team Games Tournament (TGT) learning model assisted by the game media snake ladder to the knowledge of mathematics students of grade IV SD group VIII Mengwi, Badung.
\end{abstract}

Key words: Team Games Tournament (TGT), Snake Game Tanngga, Math Knowledge 


\section{PENDAHULUAN}

Pembelajaran Matematika merupakan salah satu disiplin ilmu yang diajarkan pada semua siswa mulai dari $\mathrm{SD}$, sekolah menengah, bahkan sampai ke perguruan tinggi. Hal ini disebabkan karena Matematika diperlukan dalam berbagai aktivitas kehidupan, memecahkan masalah sehari-hari, serta membantu siswa mengembangkan kemampuan berpikir. Menurut (Susanto, 2013:185) "pembelajaran Matematika merupakan salah satu disiplin ilmu yang dapat meningkatkan kemampuan berpikir dan beragumentasi, memberikan kontribusi dalam penyelesaian masalah sehari-hari dan dalam dunia kerja, serta memberikan dukungan dalam pengembangan ilmu pengetahuan dan teknologi”. Kebutuhan akan aplikasi Matematika saat ini dan masa depan tidak hanya untuk keperluan sehari-hari, tetapi terutama dalam dunia kerja, dan untuk mendukung perkembangan ilmu pengetahuan. Oleh karena itu, Matematika sebagai ilmu dasar perlu dikuasai dengan baik oleh siswa, terutama sejak usia SD. Mengingat begitu pentingnya peranan Matematika seperti yang telah diuraikan, sudah seharusnya mata pelajaran Matematika menjadi perhatian khusus dalam bidang pendidikan khususnya di SD. Hal ini disebabkan karena, pembelajaran Matematika di SD akan menjadi dasar pada pendidikan selanjutnya. Oleh karena itu, pembelajaran Matematika di SD perlu diarahkan kepada pembentukkan pondasi yang kokoh dalam artian pembentukan konsep dasar yang kuat pada diri siswa sehingga siswa siap untuk mempelajari materi selanjutnya pada jenjang pendidikan yang lebih tinggi.

Menurut Suarni (2013:2) "Matematika merupakan salah satu bidang studi yang sangat penting ditanamkan pada diri siswa karena Matematika merupakan bidang studi yang ampuh untuk mencapai disiplin mental".Dalam kegiatan pembelajaran di kelas, guru memiliki peranan utama untuk mengelola pembelajaran. Dalam pembelajaran Matematika, guru harus dapat menciptakan suasana lingkungan yang memungkinkan seseorang (siswa) melaksanakan kegiatan belajar Matematika. Hal ini berarti pembelajaran yang berlangsung haruslah berpusat pada siswa. Dengan demikian, siswa dapat mengaktualisasikan diri untuk mengembangkan seluruh kemampuan yang ada pada dirinya khususnya kemampuan untuk berpikir serta kemampuan bekerja sama.

Namun, kenyataan di SD belum sesuai dengan kondisi yang diharapkan. Hal ini menunjukkan bahwa pembelajaran Matematika yang berlangsung masih didominasi oleh pembelajaran KTSP yang berpusat pada guru dan tidak memberikan kesempatan pada siswa untuk berkembang secara mandiri melalui penemuan dan proses berpikirnya. Penggunaan metode ceramah menjadikan siswa menjadi pasif dalam pembelajaran. Komunikasi yang terjadi hanya satu arah yakni dari guru ke siswa, sehingga siswa tidak turut aktif membangun pengetahuannya. Hal inilah yang menjadikan Matematika sebagai salah satu mata pelajaran yang membosankan dan menakutkan. Rasa bosan muncul karena siswa kurang diberi kesempatan untuk mengaktualisasikan kemampuan berpikir yang dimilikinya. Sedangkan rasa takut muncul, karena sering kali siswa hanya dijejali dengan berbagai macam rumus yang harus dihafal, sehingga pembelajaran berlangsung begitu tegang dan kaku. Suasana itu tentu saja dapat mengurangi tingkat konsentrasi dan kematangan terhadap pemahaman materi yang pada akhirnya berimbas pada hasil belajar siswa.

Berdasarkan observasi yang telah dilakukan pada hari Rabu tanggal 1 Februari 2017 di seluruh SD yang berada di Gugus VIII Mengwi, diperoleh hasil ulangan akhir pada muatan materi Matematika belum sesuai dengan yang diharapkan. Akibat nyata yang ditemui adalah nilai rata-rata ulangan harian siswa masih banyak yang di bawah KKM. Hal ini menunjukkan bahwa hasil belajar Matematika siswa kelas IV SD Gugus VIII Mengwi Badung memiliki variasi yang cukup tinggi bahkan sebagian masih dibawah Kriteria Ketuntasan Minimal (KKM=65); yakni sebanyak 35 siswa yang sudah mencapai KKM, sedangkan 206 siswa yang belum mencapai KKM. Ini diperlihatkan bahwa $15 \%$ siswa yang mampu mencapai KKM dan $85 \%$ siswa memiliki hasil belajar Matematika di bawah KKM. 
Salah satu hal yang mempengaruhi hasil belajar siswa adalah strategi ataupun model pembelajaran yang digunakan guru dalam kegiatan pembelajaran di kelas. Pembelajaran Matematika hendaknya dapat memfasilitasi siswa belajar dalam suasana yang aktif dengan adanya interaksi siswa dengan siswa maupun siswa dengan guru. Salah satu model pembelajaran yang dapat merangsang siswa untuk lebih aktif dalam proses pembelajaran dan cocok diterapkan pada mata pelajaran Matematika sehingga dapat diterapkan untuk meningkatkan kemampuan siswa dalam menyelesaikan masalah Matematika adalah model pembelajaran Team Games Tournament (TGT) berbantuan media permainan ular tangga.

Sebagai seorang guru profesional hendaknya guru mampu menguasai berbagai macam model pembelajaran yang relevan untuk meningkatkan kemampuan pemecahan masalah matematika siswa dengan kehidupan sehari-hari. Salah satu model pembelajaran yang dapat mempengaruhi kemampuan pemecahan masalah matematika siswa adalah model pembelajaran Team Games Tournament (TGT) berbantuan media permainan ular tangga.

$$
\text { Melalui penerapan model }
$$

pembelajaran Team Games Tournament (TGT) berbantuan media permainan ular tangga, dapat memberikan kesempatan kepada siswa untuk belajar dalam suasana yang aktif dan menyenangkan. Tentu saja hal tersebut berpengaruh terhadap tingkat konsentrasi, kecepatan menyerap materi pelajaran, dan kematangan pemahaman terhadap sejumlah materi pelajaran sehingga berimbas pada hasil belajar Matematika yang optimal. Model pembelajaran kooperatif yang menempatkan siswa dalam kelompokkelompok belajar bersifat heterogen, yang nantinya masing-masing perwakilan kelompok yang memiliki kemampuan setara akan dipertemukan untuk memainkan sebuah turnamen dengan tujuan untuk menguji hasil belajar yang diperoleh selama kegiatan belajar kelompok.

Menurut Komalasari (2010:67) "model pembelajaran TGT adalah salah satu tipe pembelajaran kooperatif yang mudah diterapkan, melibatkan aktivitas seluruh siswa tanpa harus ada perbedaan status, melibatkan peran siswa sebagai tutor sebaya dan mengandung unsur permainan serta reinforcement." Dalam model ini siswa ditempatkan dalam kelompok-kelompok belajar yang heterogen, setelah siswa belajar dalam kelompoknya, masing-masing perwakilan anggota kelompok yang setingkat kemampuannya akan dipertemukan untuk memainkan sebuah turnamen yang dikenal dengan "tournaments table" yang diadakan tiap akhir unit pokok bahasan atau akhir pekan. Skor yang didapat akan memberikan kontribusi rata-rata skor kelompok. Adanya turnamen akademik yang terdapat pada model pembelajaran kooperatif tipe ini adalah ciri yang dapat menjadikan pembelajaran lebih menarik terutama bagi siswa usia sekolah dasar. Seperti model-model pembelajaran lainnya, model pembelajaran TGT juga memiliki beberapa keunggulan. (Taniredja,2015:72) mengemukakan beberapa keunggulan model pembelajaran TeamGames Tournament (TGT) yaitu sebagai berikut.

Memiliki kebebasan untuk berinteraksi dan menggunakan pendapatnya, karena dalam kelas kooperatif diberikan kesempatan seluas-luasnya untuk berinteraksi secara aktif, (b) Meningkatkan rasa percaya diri, (c) Mengurangi perilaku menganggu terhadap sesama siswa saat pembelajaran berlangsung, (d) Meningkatkan motivasi belajar, (e) Meningkatkan kebaikan budi, kepekaan, toleransi sesama siswa dan antara siswa dengan guru, (f) Dalam kelas kooperatif pelajar dapat menelaah sebuah materi atau pokok bahasan, mengaktualisasikan diri dengan seluruh potensi yang ada dalam diri, kerja sama yang terjadi antar siswa, maupun siswa dengan guru membuat interaksi belajar dalam kelas menjadi hidup dan tidak membosankan.

Jika tidak jeli dalam mengelola kelas dan siswa, akan menjadi penyebab kegagalan penerapan model pembelajaran TeamGames Tournament (TGT) sebab dibutuhkan kecerdasan emosi untuk memotivasi siswa dalam mengaktualisasikan diri dan mengelola waktu dengan sebaik mungkin.

Dalam implementasinya model pembelajaran TGT dapat diintegrasikan 
dengan media pembelajaran. Tentu saja pemilihan media pembelajaran harus benarbenar menjadi petimbangan baik dari segi kesesuaian materi pelajaran maupun dari segi karakteristik siswa. Salah satu karakteristik dari anak SD adalah bermain. Bagi anak bermain merupakan kebutuhan yang tidak dapat ditinggalkan. Aisyah (2007:2.25) berpendapat bahwa "jika guru dapat mengemas permainan sebagai media maupun pendekatan dalam belajar matematika bagi anak, maka anak akan senang belajar matematika sehingga menjadi efektif untuk mendapatkan hasil belajar yang optimal."

Permainan yang digunakan dapat diadopsi dari permainan sehari-hari yang sudah dikenal oleh siswa. Tentu saja permainan yang dimaksud bukan sembarang permainan. Dengan kata lain permainan yang digunakan haruslah memiliki nilai edukatif. Menurut (Erlin, 2013:5) "beberapa hal yang dapat dijadikan acuan permainan yang digunakan bersifat edukatif antara lain: (1) sesuai dengan sasaran, (2) multifungsi, (3) sesuai dengan tujuan, (4) melatih konsepkonsep dasar, (5) merangsang kreativitas".

Ada berbagai jenis permainan edukatif yang dapat dijadikan media sebagai media pembelajaran. "Salah satunya adalah permainan ular tangga. Permainan ular tangga merupakan permainan kelompok yang melibatkan beberapa orang yang tidak dapat digunakan secara individu (Erlin, 2013:6)". Pada permainan ular tangga, medan permainan adalah sebuah papan atau karton bergambar kotak-kotak biasanya berukuran 10x10 kotak. Tiap kotak diberi nomor urut mulai dari nomor 1 dari sudut kiri bawah sampai nomor 10 di sudut kanan bawah, lalu dari kanan ke kiri mulai nomor 11 baris kedua sampai nomor 20 dan seterusnya sampai nomor 100 di sudut kiri atas.

Berdasarkan uraian tersebut, maka diadakan penelitian yang berjudul "Pengaruh Model pembelajaran Team Games Tournament (TGT) Berbantuan Media Permainan Ular Tangga terhadap Hasil Belajar Matematika Siswa Kelas IV SD Gugus VIII Mengwi, Badung Tahun Pelajaran 2016/2017".

Tujuan dari penelitian ini adalah untuk untuk mengetahui pengaruh model pembelajaran Team Games Tournament (TGT) berbantuan media permainan ular tangga terhadap hasil belajar Matematika siswa kelas IV di SD Gugus VIII Mengwi, Badung.

\section{METODE PENELITIAN}

Penelitian ini dilaksanakan pada siswa kelas IV SD Gugus VIII Mengwi, Badung. Penelitian yang dilaksanakan ini merupakan jenis penelitian eksperimen. Desain eksperimen yang digunakan dalam penelitian ini adalah rancangan kelompok NonEkuivalen. Rancangan penelitian ini dikategorikan sebagai rancangan eksperimen semu (quasi-experimental), karena dalam pemilihan subjek penelitian, tidak selalu dapat dilakukan pemilihan subjek secara random. Dalam penelitian ini tidak memungkinkan memilih dan memilah subjek sesuai dengan rancangan, karena kelas atau kelompok subjek telah ditentukan oleh sekolah.Rancangan penelitian ini sering digunakan dalam penelitian. Dalam rancangan ini ada dua kelompok yaitu, satu kelompok mendapat perlakuan yang disebut sebagai kelas eksperimen dan satu kelompok sebagai kelompok kontrol atau kelas kontrol. Kelompok kontrol dan eksperimen sama-sama memperoleh pre-test dan post-test. Rancangan ini digambarkan sebagai berikut.

\begin{tabular}{|lrrl|}
\hline O1 & $\mathrm{X}$ & $\mathrm{O} 2$ & (Eksperimen) \\
\hdashline $\mathrm{O} 3$ & & $\mathrm{O} 4$ & (Kontrol) \\
\hline
\end{tabular}

Gambar 1. Rancangan Eksperimen (Sumber: Setyosari, 2015:211)

Populasi penelitian ini adalah siswa kelas IV SD Negeri di Gugus VIII Mengwi, Badung, yang terdiri dari terdapat 7 SD (6 kelas) yang keseluruhannya berjumlah 243 siswa. Dalam penelitian ini sampel yang dipilih adalah dua kelas, yaitu satu kelas eksperimen dan satu kelas kontrol. Kedua kelas tersebut diberikan perlakukan yang berbeda. Satu kelas diberikan perlakuan dengan model pembelajaran Team Games Tournament (TGT) berbantuan media permainan ular tangga dan satu kelas lagi 
tidak dibelajarkan dengan model pembelajaran Team Games Tournament (TGT) berbantuan media permainan ular tangga. Pengambilan sampel dalam penelitian ini menggunakan teknik Random Sampling. "Random sampling adalah teknik pengambilan samplel yang dilakukan secara acak" (Sugiyono,2012:82). Kesetaraan sampel diuji dengan rumus uji-t yakni dengan polled varian. Dalam sebuah penelitian terdapat beberapa metode pengumpulan data. Setyosari (2015) mengungkapkan metode pengumpulan data merupakan cara data penelitian diperoleh. Pengumpulan data hasil belajar Matematika dilakukan dengan metode tes.

Menurut Agung (2014), metode tes dalam kaitannya dengan penelitian ialah cara memperoleh data yang berbentuk suatu tugas yang dilakukan atau dikerjakan oleh seseorang atau sekelompok orang yang dites (testee) dan dari tes tersebut dapat menghasilkan suatu data berupa skor (data interval), metode ini sangat tepat untuk mengukur hasil belajar Matematika karena pada umumnya metode tes banyak digunakan untuk mengukur ranah kognitif tes yang digunakan adalah berupa tes objektif pilihan ganda biasa. Pada penelitian ini, instrumen yang digunakan untuk mengumpulkan data hasil belajar Matematika adalah tes pengetahuan secara tertulis menggunakan tes objektif (Multiple Choise Test).

Sebelum membuat butir tes, peneliti menyusun kisi - kisi (blue print) agar tes yang dibuat tidak menyimpang dari materi pelajaran. Aspek kognitif yang diteliti dalam penelitian ini hanya empat tingkatan kemampuan berpikir saja, yakni pengetahuan (C1), pemahaman $(\mathrm{C} 2)$, penerapan $(\mathrm{C} 3)$, dan analisis (C4). Menurut Suharsimi (2013: 183) "Multiple Choise Test terdiri atas suatu keterangan atau pemberitahuan tentang suatu pengertian yang belum lengkap dan untuk melengkapinya harus memilih satu dari beberapa kemungkinan jawaban yang telah disediakan". Tes pilihan ganda terdiri atas bagian keterangan dan bagian kemungkian jawaban atau alternaif (option). Kemungkinan jawaban (option) terdiri atas satu jawaban yang benar yaitu kunci jawaban dan beberapa pengecoh (distractor).
Data yang telah diperoleh kemudian dianalisis dengan menggunakan statistik deskriptif.Sugiyono (2012:29) menyatakan, "Statistik deskriptif adalah statistik yang berfungsi untuk mendiskripsikan atau memberi gambaran terhadap objek yang diteliti melalui data sampel atau populasi sebagaimana adanya, tanpa melakukan analisis dan membuat kesimpulan yang berlaku untuk umum". Statistik ini digunakan untuk mencari mean, standar deviasi dan varians. Setelah itu data yang telah diperoleh juga diuji dengan uji prasyarat analisis data, menggunakan statistic inferensial. "Statistik inferensial adalah teknik statistik yang digunakan untuk menganalisis data sampel dan hasilnya diberlakuakn untuk populasi" (Sugiono, 2012:148).

Teknik analisis data yang dilakukan untuk menguji hipotesis dengan menggunakan uji-t, terlebih dahulu dilakukan uji prasyarat analisis yang meliputi uji normalitas dan homogenitas varians. Uji normalitas sebaran dilakukan untuk menyajikan bahwa sampel benar-benar berasal dari populasi yang berdistribusi normal. Uji normalitas data untuk skor kemampuan memecahkan masalah matematika siswa digunakan analisis ChiSquare. Sedangkan uji homogenitas merupakan analisis prasyarat sebelum dilakukan uji hipotesis. Uji ini dilakukan mengetahui sebaran data benar benar homogen. Uji homogenitas untuk kedua kelompok digunakan uji F. Setelah uji prasyarat dilanjutkan dengan pengujian hipotesis. Teknik analisis d digunakan untuk menguji hipotesis dalam penelitian ini, yaitu menggunakan analisis uji-t dengan polled varians.

\section{HASIL DAN PEMBAHASAN}

Berdasarkan data pada Tabel 1 diketahui bahwa mean data hasil belajar matematika siswa pada kelompok eksperimen $=79,35$ lebih dari daripada mean data hasil belajar matematika siswa pada kelompok kontrol $=72,85$. 
Tabel 1. Deskripsi Data Kemampuan Pemecahan Masalah Kelompok Eksperimen dan Kelompok Kontrol

\begin{tabular}{ccc}
\hline Statistik & Eksperimen & Kontrol \\
\hline Rata-rata & 79,35 & 72,85 \\
Standar Deviasi & 44,70 & 5,52 \\
Varians & 6,69 & 30,45 \\
\hline
\end{tabular}

Uji prasyarat dilakukan terlebih dahulu sebelum uji hipotesis menggunakan uji-t. Uji prasyarat tersebut meliputi uji normalitas dan uji homogenitas varians diuraikan berikut ini.

Uji normalitas dilakukan untuk mengetahui sebaran frekuensi skor, untuk menguji data hasil belajar matematika kelompok eksperimen dan kontrol adalah rumus Chi Kuadrat. Kriteria pengujian pada uji normalitas adalah jika $\mathrm{x}^{2}$ hitung $<\mathrm{x}^{2}$ tabel maka sebaran data kedua kelompok berdistribusi normal. Berdasarkan hasil uji normalitas kelompok eksperimen, diperoleh Chi Kuadrat hitung $\left(\mathrm{x}^{2}\right.$ hitung $\left.=4,19\right)$ kemudian nilai tersebut dibandingkan dengan Chi Kuadrat tabel yang bertaraf signifikan 5\% dk $58\left(\mathrm{x}^{2}{ }_{\text {tabel }}=11,07\right)$. Hal ini menunjukkan bahwa $x^{2}$ hitung $<x^{2}$ tabel berarti data hasil belajar matematika kelompok eksperimen berdistribusi normal. Berdasarkan hasil uji normalitas kelompok kontrol, diperoleh Chi Kuadrat hitung ( $\mathrm{x}^{2}$ hitung $=8,55)$ kemudian nilai tersebut dibandingkan dengan Chi Kuadrat tabel $\left(x_{\text {tabel }}^{2}=11,07\right)$. Hal ini menunjukkan bahwa $x^{2}{ }_{\text {hitung }}<\mathrm{x}^{2}$ tabel berarti data hasil belajar matematika kelompok kontrol berdistribusi normal.

Pengujian homogenitas varians antar kelompok dimaksudkan untuk meyakinkan bahwa perbedaan yang diperoleh uji-t benar benar berasal dari perbedaan antar kelompok bukan disebabkan oleh perbedaan di dalam kelompok. Uji homogenitas varians yang dilakukan dalam penelitian ini menggunakan uji $\mathrm{F}$ dari Havley. Dari hasil analisis, diperoleh $\mathrm{F}_{\text {hitung }}=1,37$ dan $\mathrm{F}_{\text {tabel }}=1,85$. Hal ini berarti $\mathrm{F}_{\text {hitung }}<\mathrm{F}_{\text {tabel }}$, sehingga data kedua kelompok memiliki varians yang homogen. Berdasarkan hasil uji prasyarat yang terdiri dari uji normalitas dan uji homogenitas varians, disimpulkan bahwa data kedua kelompok sampel ialah berdistribusi normal dan memiliki varians yang homogen. Dengan demikian, uji hipotesis menggunakan uji-t dapat dilakukan. Hipotesis yang akan diuji dalam penelitian ini adalah tidak terdapat perbedaan yang signifikan hasil belajar Matematika kelompok siswa yang dibelajarkan melalui model pembelajaran Team Games Tournament (TGT) berbantuan media permainan ular tangga dan kelompok siswa yang tidak dibelajarkan melalui model pembelajaran Team Games Tournament (TGT) berbantuan media permainan ular tangga. Hasil uji prasyarat yang meliputi uji normalitas dan homogenitas varians yang dilakukan dalam penelitian ini diperoleh kedua kelompok sampel berdistribusi normal dan memiliki varians yang homogen. Analisis statistik yang digunakan untuk menguji hipotesis penelitian ini adalah uji-t dengan polled varians. Rekapitulasi hasil analisis uji-t kelompok sampel penelitian ini disajikan dalam Tabel 2.

Tabel 2. Rekapitulasi Hasil Analisis Uji-t Kelompok Sampel Penelitian

\begin{tabular}{lllllll}
\hline No & Kelompok Sampel & $\mathrm{N}$ & $\mathrm{Dk}$ & $\mathrm{M}$ & $\mathrm{t}_{\text {hitung }}$ & $\mathrm{t}_{\text {tabel }}$ \\
\hline 1. & Eksperimen & 30 & & 58 & 4,19 & \\
2. & Kontrol & 30 & & & 8,10 & 2,000 \\
\hline
\end{tabular}


Berdasarkan uji hipotesis diperoleh $\mathrm{t}_{\text {hitnung }}=4,10$ sedangkan pada taraf signifikansi $5 \%$ dan $\mathrm{dk}=58$ diperoleh nilai $\mathrm{t}_{\text {tabel }}=2,000$ sehingga $\mathrm{t}_{\text {hitnung }}=4,10>\mathrm{t}_{\text {tabel }}=$ 2,000 . Dengan demikian, hipotesis nol (Ho) ditolak. Hal ini berarti terdapat perbedaan yang signifikan hasil belajar Matematika kelompok siswa yang dibelajarkan melalui model pembelajaran Team Games Tournament (TGT) berbantuan media permainan ular tangga dan kelompok siswa yang tidak dibelajarkan melalui model pembelajaran Team Games Tournament (TGT) berbantuan media permainan ular tangga. Perolehan hasil perhitungan analisis data yang dilakukan menunjukkan bahwa nilai rerata siswa yang dibelajarkan menggunakan model pembelajaran Team Games Tournament (TGT) berbantuan media permainan ular tangga $(\bar{X}=79,35)$ dan siswa yang tidak dibelajarkan menggunakan model pembelajaran Team Games Tournament (TGT) berbantuan media permainan ular tangga $(\bar{X}=72,85)$ memiliki perbedaan sebesar 6,5. Dengan demikian, terdapat pengaruh model pembelajaran Team Games Tournament (TGT) berbantuan media permainan ular tangga terhadap hasil belajar Matematika siswa kelas IV di SD Gugus VIII Mengwi, Badung Tahun Pelajaran 2016/2017.

Berdasarkan hasil temuan tersebut, dapat dinyatakan kedua kelompok sampel penelitian yang memiliki kemampuan setara, setelah diberikan perlakuan berupa pembelajaran dengan menggunakan model pembelajaran Team Games Tournament (TGT) berbantuan media permainan ular tangga dan dengan yang tidak menggunakan model pembelajaran Team Games Tournament (TGT) berbantuan media permainan ular tangga diperoleh hasil belajar Matematika yang berbeda. Hal ini dapat dilihat juga dari $\bar{X}$ siswa yang dibelajarkan menggunakan model pembelajaran Team Games Tournament (TGT) berbantuan media permainan ular tangga lebih tinggi dibandingkan dengan $\bar{X}$ siswa yang tidak dibelajarkan menggunakan model pembelajaran Team Games Tournament (TGT) berbantuan media permainan ular tangga. Perbedaan hasil belajar Matematika dengan perolehan nilai rerata yang lebih tinggi pada kelompok eksperimen dibandingkan kelompok kontrol disebabkan oleh perlakuan berupa model pembelajaran Team Games Tournament (TGT) berbantuan media permainan ular tangga dalam mata pelajaran Matematika yang diberikan pada kelompok eksperimen.

Pada kelompok eksperimen, kegiatan pembelajaran dalam mata pelajaran Matematika menggunakan model pembelajaran Team Games Tournament (TGT) berbantuan media permainan ular tangga berjalan dengan optimal dan kondusif. Hal ini disebabkan karena dengan menerapkan model pembelajaran Team Games Tournament (TGT) berbantuan media permainan ular tangga siswa diberikan kesempatan untuk terlibat aktif, tidak hanya mendengar keterangan guru tetapi berperan aktif untuk menggali, menganalisis, mengevaluasi pemahamannya terhadap konsep yang dipelajari. Selain itu pembelajaran yang dilakukan secara berkelompok juga sangat membantu siswa dalam menumbuhkan orisinilitas ide, kreatifitas, kognitif tinggi, kekritisan pemikiran siswa, komunikasi-interaksi, sharing, keterbukaan, dan sosialisasi dalam diskusi yang dilakukan dalam kelompok. Dengan dihadapkannya siswa terhadap masalah dalam pembelajaran Matematika juga menjadikan proses pembelajaran menjadi lebih bermakna, karena apa yang dipelajari siswa menyangkut kepada masalah yang kerap kali ditemui oleh siswa dalam kehidupan nyata dan akan dapat diterapkan nantinya dalam kehidupan sehari-hari.

Berbeda dengan pembelajaran Matematika yang biasanya digunakan dengan metode ceramah, selama proses pembelajaran siswa terlihat kurang aktif. Proses pembelajaran masih berpusat pada guru (teacher centre) yang lebih banyak memberikan ceramah daripada kegiatan yang melibatkan siswa secara aktif dalam proses pembelajaran. Pembelajaran yang terlalu banyak menggunakan metode ceramah ini mengakibatkan siswa sangat tergantung pada guru, hal ini dapat mengakibatkan hasil belajar siswa kurang optimal. Sehingga siswa hanya menerima 
apa yang disampaikan guru dan proses pembelajaran cenderung membosankan.Hal ini mendukung hipotesis yang menyatakan bahwa terdapat perbedaan yang signifikan pengetahuan Matematika siswa yang dibelajarkan menggunakan model pembelajaran Team Games Tournament (TGT) berbantuan media permainan ular tangga dan siswa yang tidak dibelajarkan menggunakan model pembelajaran Team Games Tournament (TGT) berbantuan media permainan ular tangga pada siswa kelas IV SD Gugus VIII Mengwi, Badung tahun pelajaran 2016/2017.

Hasil temuan pada penelitian ini memiliki persamaan dengan penelitian sebelumnya yang relevan dan memperkuat hasil penelitian yang diperoleh. Hal tersebut didukung hasil penelitian yang diajukan oleh Purwantini (2013) yang menyatakan hasil belajar Matematika kelompok siswa yang dibelajarkan dengan model pembelajaran Team Games Tournament (TGT) berbantuan media permainan ular tangga lebih tinggi dibandingkan dengan kelompok siswa yang tidak dibelajarkan dengan model pembelajaran Team Games Tournament (TGT) berbantuan media permainan ular tangga. Tinjauan ini didasarkan pada ratarata skor kemampuan pemecahan masalah matematika siswa. Rata-rata skor kemampuan pemecahan masalah matematika siswa yang dibelajarkan dengan model pembelajaran Team Games Tournament (TGT) berbantuan media permainan ular tangga adalah 79,35 berada pada kategori cukup dan rata-rata skor kemampuan pemecahan masalah matematika siswa yang tidak mengikuti pembelajaran Team Games Tournament (TGT) berbantuan media permainan ular tangga adalah 72,85 berada pada kategori cukup.

\section{SIMPULAN DAN SARAN}

Berdasarkan hasil analisis dengan menggunakan uji-tdiperoleh $t_{\text {hitung }}=4,26$. Harga tersebut kemudian dibandingkan dengan harga $t_{\text {tabel }}$ dengan $\mathrm{dk}=58$ pada taraf signifikansi $5 \% \mathrm{t}_{\text {tabel }}=2,000$ ini berarti bahwa terdapat perbedaan yang signifikan hasil belajar Matematika siswa kelas IV di
SD Gugus VIII Mengwi Tahun Pelajaran 2016/2017 yang mengikuti pembelajaran yang menggunakan model pembelajaran Team Games Tournament (TGT) berbantuan media permainan ular tangga dan siswa yang tidak menggunakanmodel pembelajaran Team Games Tournament (TGT) berbantuan media permainan ular tangga. Sehingga dapat disimpulkan bahwa model pembelajaran Team Games Tournament (TGT) berbantuan media permainan ular tangga berpengaruh terhadap hasil belajar Matematika siswa kelas IV SD Gugus VIII Tahun Pelajaran 2016/2017.

Adapun saran yang disampaikan: Pertama, Kepada Guru. Berdasarkan temuan penelitian yang diperoleh, disarankan kepada guru agar lebih kreatif untuk memberikan fasilitas berupa sumber belajar dan kesempatan yang lebih besar bagi siswa pada pembelajaran dengan menggunakan model pembelajaran Team Games Tournament (TGT) berbantuan media permainan ular tangga sehingga tercipta pembelajaran bermakna dan menyenangkan bagi siswa.

Kedua, Kepada Sekolah. Berdasarkan temuan penelitian, disarankan kepada kepala sekolah agar dapat menggunakan hasil penelitian ini sebagai pendukung sumber belajar guru dalam meningkatkan kualitas pembelajaran dengan menciptakan pembelajaran yang menyenangkan di sekolah sehingga sekolah mampu menghasilkan siswa yang berkualitas.

Ketiga, Kepada Peneliti Lain. Berdasarkan temuan penelitian, disarankan kepada peneliti agar hasil penelitian ini digunakan sebagai referensi untuk melaksanakan penelitian selanjutnya atau menemukan inovasi kegiatan pembelajaran lainnya yang bermakna dan menyenangkan bagi siswa

\section{DAFTAR RUJUKAN}

Agung, A. A. Gede. 2014. Metodologi Penelitian Pendidikan. Singaraja: FIP Undiksha

Aisyah, Nyimas, dkk. 2007. Pengembangan Pembelajaran Matematika SD. Jakarta: Departemen Pendidikan Nasional 
Arikunto, Suharsimi. 2015. Dasar-dasar Evaluasi Pendidikan. Jakarta: PT Bumi Aksara

Komalasari, Kokom. 2010. Pembelajaran Kontestual Konsep dan Aplikasi. Bandung: Refika Aditama.

Nopiani Erlin, dkk. 2013. Model Pembelajaran TGT Berbantuan Media Ular Tangga Berpengaruh Terhadap Hasil Belajar Matematika Siswa Kelas IV SD Gugus VIII Sukawati. Singaraja: Universitas Pendidikan Ganesh. Tersedia pada http://ejournal.undiksha.ac.id/index .php/JJPGSD/article/viewFile/3010 12494 (diakses tanggal 4 Februari 2017), Volume 2, Nomor 1 (hlm. 1-10)

Setyosari, Punaji, 2015. Metode Penelitian dan Pengembangan. Jakarta: Prenanda Media Grup

Suarni, Putu. 2013. Pengaruh Model Pembelajaran Matematika Realistik Terhadap Hasil Belajar Pada Mata Pelajaran Matematika Kelas V Sd Di Gugus Iii Kecamatan Banjar.Singaraja: Universitas Pendidikan Ganesha. Tersedia pada file:

index.php/JJPGSD/article/view/912 /782 (diakses pada tanggal 20 Juli 2017), Volume 1. Nomor 1 (hlm. 110)

Sugiyono. 2012. Metode Penelitian Kuantitatif Kualitatif dan $R \& D$. Bandung: Alfabeta

Susanto. 2013. Teori Belajar dan Pembelajaran. Jakarta: Prenadamedia Group

Taniredja, dkk. 2015. Model-model Pembelajaran Inovatif dan Efektif. Bandung: Alfabeta, cv 